\title{
MODEL PEMBELAJARAN KOOPERATIF TIPE GROUP INVESTIGATION (GI) MENINGKATKAN AKTIVITAS DAN HASIL BELAJAR SEJARAH
}

\author{
Tri Hartoto \\ Guru Sejarah SMA Negeri 1 Punggur \\ email: trihartoto@gamil.com
}

\begin{abstract}
Abstrak
Penelitian ini bertujuan untuk meningkatkan aktivitas siswa sehingga berdampak pada hasil belajar sejarah siswa kelas XII IPA SMA Negeri I Puggur Tahun Pelajaran 2015/2016. Metode penelitian menggunakan tindakan kelas (action research). Pembelajaran kooperatif tipe $\mathrm{Gl}$ dapat meningkatkan kualitas pembelajaran sejarah. Pembelajaran kooperatif tipe GI memiliki dampak positif dalam meningkatkan prestasi belajar siswa yang ditandai dengan peningkatan ketuntasan belajar siswa dalam setiap siklus, yaitu siklus I (72,5\%), siklus II (80,0\%), siklus III (92,5\%). Pembelajaran kooperatif tipe GI dapat menjadikan siswa merasa dirinya mendapat perhatian dan kesempatan untuk menyampaikan pendapat, gagasan, ide dan pertanyaan.
\end{abstract}

Kata kunci: pembelajaran, kooperatif, group investigation, sejarah

\begin{abstract}
This research aims to increase student activity so the impact on learning outcomes for students the history of class XII Science SMAN I Puggur in academic year 2015/2016. The research method uses a class action (action research). Gl cooperative learning can improve the quality of teaching history. Gl cooperative learning has a positive impact in improving student achievement marked by increased mastery learning students in each cycle, the first cycle (72.5\%), the second cycle (80.0\%), the third cycle (92.5\%) , GI cooperative learning can make students feel themselves to get attention and the opportunity to express their opinions, ideas, ideas and questions.
\end{abstract}

Keywords: learning, cooperative, group investigation, history

\section{PENDAHULUAN}

Pendidikan menjadi salah satu modal penting untuk memajukan sebuah bangsa karena kesejahteraan dan kemajuan sebuah bangsa dapat dilihat dari tingkat pendidikannya. Pendidikan memegang peranan penting dalam menciptakan individu berkualitas. Pendidikan memerlukan inovasi-inovasi yang sesuai dengan kemajuan ilmu pengetahuan dan teknologi tanpa mengabaikan nilai-nilai kemanusiaan. Pendidikan juga dipandang sebagai sarana untuk melahirkan insan-insan yang cerdas, kreatif, terampil, bertanggung jawab, produktif, dan berbudi pekerti luhur.

$$
\text { Berbagai upaya telah dilakukan }
$$
pemerintah dalam meningkatkan mutu pendidikan nasional, salah satunya dengan melakukan inovasi dalam dunia pendidikan. Inovasi yang dilakukan biasanya dengan memperhatikan tiga alasan penting, yaitu efisien, efektif, dan kenyamanan. Efisien maksudnya waktu yang tersedia bagi guru harus 
dimanfaatkan sebaik-baiknya. Efektif maksudnya pelajaran yang diberikan harus menghasilkan suatu hasil yang bermanfaat bagi peserta didik atau masyarakat, sedangkan kenyamanan berarti sumber belajar, media alat bantu belajar, metode yang dipilih harus mampu membangkitkan motivasi atau gairah baik bagi peserta didik maupun bagi guru dalam proses pembelajaran sehingga dapat tercapai tujuan pembelajaran yang diinginkan.

Peningkatkan mutu pendidikan yang dilakukan oleh pemerintah, guru, dan orang tua selalu berupaya untuk meningkatkan prestasi belajar peserta didik. Namun, usaha-usaha yang telah dilakukan tersebut belum menunjukkan hasil yang memuaskan, khususnya pada mata pelajaran sejarah.

Selama mengajar di SMA Negeri 1 Puggur, peneliti yang juga guru sejarah di sekolah ini belum mampu mendapatkan hasil yang maksimal. Hal ini tercermin pada nilai uji blok I di kelas XII IPA semester ganjil tahun 2015/2016. Nilai rata-rata sejarah siswa dikelas ini adalah 43,89 dimana siswa yang memperoleh nilai di atas 60 sebanyak $47,22 \%$.

Selama pembelajaran, guru menggunakan beberapa model pembelajaran, diantaranya model pembelajaran drill dan diskusi. Pada model pembelajaran drill, banyak siswa yang mengeluh dan malas mengikuti pembelajaran, dikarenakan siswa bekerja sendiri-sendiri. Siswa yang pandai semakin pandai dan siswa yang tidak pandai semakin malas untuk belajar. Pada diskusi kelompok, seyogyanya terjadi kerjasama yang baik antar sesama anggota dalam kelompok tersebut. Namun, pada kenyataannya siswa yang berkemampuan rendah menjadi malas untuk berusaha. Mereka lebih suka menunggu hasil kerja dari murid yang pandai. Hal ini menyebabkan murid yang pandai merasa kecewa dan dirugikan. Terlebih lagi mereka tidak pernah diberikan penghargaan dari usahanya itu.

Uraian diatas menjelaskan betapa rendahnya aktivitas belajar siswa kelas XII IPA SMA Negeri 1 Puggur. Hal tersebut bukan berarti menyimpulkan bahwa model pembelajaran drill dan diskusi kelompok itu tidak baik. Kedua model pembelajaran tersebut baik, namun kurang cocok diterapkan pada siswa kelas XII IPA.

Pemilihan model pembelajaran yang tepat sangatlah penting agar tujuan pembelajaran dapat tercapai. Meskipun tujuan pembelajaran dirumuskan dengan baik, materi yang dipilih sudah tepat, jika model pembelajaran yang dipergunakan kurang memadai mungkin tujuan yang diharapkan tidak tercapai dengan baik. Jadi, model pembelajaran merupakan salah satu komponen pembelajaran yang penting dan sangat 
menentukan dalam keberhasilan proses pembelajaran. Model pembelajaran yang seharusnya merupakan interaksi guru dengan peserta didik, serta interaksi antar peserta didik yang akan membentuk sinergi yang saling menguntungkan semua anggota (Anita Lie, 2008:33). Supaya pembelajaran sejarah dapat menghasilkan hasil yang optimal, hendaknya guru harus pandai memilih model pembelajaran yang mampu melibatkan peserta didik berperan aktif dalam proses pembelajaran. Oleh karena itu, bagaimanapun tepat dan baiknya bahan ajar sejarah yang ditetapkan belum menjamin akan tercapainya tujuan pendidikan, dan salah satu faktor penting untuk mencapai tujuan tersebut adalah proses pembelajaran yang lebih menekankan pada keterlibatan peserta didik secara optimal.

Sejumlah model pembelajaran telah diterapkan di berbagai sekolah untuk meningkatkan kualitas proses pembelajaran. Namun, mengingat adanya variasi tujuan yang ingin dicapai, adanya lingkungan belajar yang berlainan, keadaan peserta didik yang berbeda, karakteristik materi yang berbeda maka tidak dapat disusun suatu model pembelajaran yang cocok untuk semua jenis kegiatan pembelajaran. Di dalam proses pembelajaran, guru harus memiliki strategi agar peserta didik bekerja secara efektif dan efisien, tepat pada tujuan yang diharapkan. Banyak model pembelajaran yang dapat digunakan dalam pembelajaran sejarah tetapi tidak setiap model pembelajaran dapat diterapkan dalam setiap materi sehingga pemilihan model pembelajaran sangatlah penting guna mencapai tujuan pembelajaran. Oleh karena itu, sebelum pelaksanaan kegiatan pembelajaran diperlukan pemikiran yang matang dalam pemilihan model pembelajaran yang tepat untuk suatu kompetensi dasar yang akan disajikan.

\section{Pengertian Hasil Belajar}

Model pembelajaran kooperatif merupakan suatu model pembelajaran kelompok yang dalam proses pembelajaran berpusat pada peserta didik sehingga dalam proses pembelajaran menghendaki peserta didik aktif dan adanya kerjasama antar anggota kelompok. Melalui pembelajaran kooperatif peserta didik secara aktif dan kooperatif bersama peserta didik yang lainnya mengkonstruksikan pengetahuannya melalui diskusi kelompok.

Menurut Dimyati (1999: 3), hasil belajar merupakan hasil dari suatu interaksi tindak belajar dan tindak mengajar. Dari sisi guru, tindak mengajar diakhiri dengan proses evaluasi hasil belajar. Dari sisi siswa, hasil belajar merupakan berakhirnya penggal dan puncak proses belajar. 
Abdurrahman (1999 : 28) mengatakan bahwa "belajar merupakan proses dari seorang individu yang berupaya mencapai tujuan belajar atau yang disebut hasil belajar, yaitu suatu bentuk perubahan perilaku yang relatif menetap". Keller dalam Abdurrahman (1999 : 39) menambahkan "hasil belajar merupa-kan prestasi aktual yang ditampilkan oleh anak". Sedangkan Tabrani (1991 : 51), mengatakan bahwa "prestasi belajar adalah hasil yang diperoleh siswa berupa pernyataan dalam bentuk angka dan nilai tingkah laku".

Hasil belajar yang diperoleh siswa setelah mengikuti proses pembelajaran berbeda-beda. Perbedaan hasil belajar tersebut disebabkan oleh beberapa faktor. Hamalik (2004: 183) mengatakan bahwa "perbedaan hasil belajar di kalangan para siswa disebabkan oleh berbagai alternatif faktor-faktor, antara lain: faktor kematangan akibat dari kemajuan umur kronologis, latar belakang pribadi masing-masing, sikap dan bakat terhadap suatu bidang pelajaran yang diberikan". Menurut Soekamto (1997) Prestasi belajar anak sangat ditentukan oleh aktivitas yang dilakukan oleh anak itu sendiri.

Berdasarkan pendapat di atas, hasil belajar siswa dipengaruhi oleh beberapa faktor, salah satunya adalah aktivitas. Aktivitas belajar yang dilakukan oleh siswa mempunyai pengaruh yang besar terhadap hasil belajarnya. Siswa yang aktif cenderung mendapatkan nilai yang tinggi dibandingkan siswa yang kurang aktif.

\section{Pengertian Pembelajaran Kooperatif}

Pembelajaran dibangun atas dasar teori atau prinsip tertentu. Pembelajaran kooperatif dibangun atas dasar teori konstruktivis sosial dari Vygotsky, teori konstruktivis personal dari Piaget dan teori motivasi. Menurut prinsip utama teori Vygotsky, perkembangan pemikiran merupakan proses sosial sejak lahir, artinya lebih kepada sebuah pengalaman. Kegiatan belajar adalah kegiatan aktif peserta didik menemukan sesuatu dan membangun sendiri aspek kognitif, afektif, dan psikomotornya. Dalam mengonstruksi pengetahuan tersebut, seorang anak dapat melakukannya baik secara berkelompok maupun individual. Paul Suparno (2001:21) mengungkapkan "anak dalam membangun pengetahuannya dapat dibantu oleh orang lain yang lebih kompeten di dalam keterampilan dan teknologi dalam kebudayaannya." Dengan adanya bantuan orang dewasa atau teman sebaya yang memiliki kemampuan lebih dalam suatu kelompok maka pemahaman kemampuannya akan meningkat.

$$
\text { Pembelajaran }
$$

kooperatif (Cooperative Learning) merupakan salah satu bentuk model pembelajaran sosial 
yang didasarkan pada teori belajar konstruktivisme. Beberapa ahli pendidikan berpendapat bahwa model pembelajaran kooperatif tidak hanya unggul dalam memudahkan peserta didik memahami dan menerapkan konsep, namun juga dalam mengembangkan kemampuan kerjasama, berpikir kritis dan sikap percaya diri yang dimiliki oleh peserta didik. Pembelajaran kooperatif adalah pendekatan pem-belajaran yang berfokus pada penggunaan kelompok kecil peserta didik untuk bekerjasama dalam memaksimalkan kondisi belajar demi tercapainya tujuan belajar.

Slavin (2009:26) menyatakan pembelajaran kooperatif adalah pembela-jaran teman sebaya dimana peserta didik bekerja dalam kelompok kecil yang memiliki latar belakang kemampuan yang berbeda. Menurut Anita Lie (2008:34), pembelajaran kooperatif adalah pembelajaran yang memberikan kesempatan peserta didik untuk bekerjasama dalam mengerjakan tugas terstruktur. Pembelajaran kooperatif dapat menjadi alternatif pembelajaran yang menarik yang dapat mencegah timbulnya keagresifan dalam sistem kompetisi dan keterasingan individual peserta didik tanpa mengorbankan aspek kognitif yang dimiliki peserta didik tersebut.

\section{Group Investigation (GI) Pada Bidang} Studi Sejarah
Group Investigation merupakan pembelajaran kooperatif yang me-nuntut peserta didik untuk lebih aktif dalam mengembangkan sikap dan pengetahuannya tentang sejarah sesuai dengan kemampuan masing-masing sehingga mereka mendapat pengertian yang lebih bermakna.

Model pembelajaran kooperatif tipe $G I$ akan lebih efektif jika guru memahami komponen penting dalam pembelajaran kooperatif. Selain itu, guru juga perlu menilai kemampuan peserta didik untuk merencanakan pembelajaran, memilih topik yang sesuai untuk GI, berpikir berdasarkan pertanyaan-pertanyaan yang muncul dari permasalahan dan menggunakan berbagai sumber untuk bahan pembelajaran.

Keuntungan bagi peserta didik dengan digunakannya model pembelajaran kooperatif tipe $G I$ antara lain adalah:

a. Peserta didik dapat bekerja secara bebas dalam proses belajar;

b. Peserta didik dapat belajar untuk memecahkan dan menangani suatu masalah;

c. Dapat memberi semangat untuk berinisiatif, kreatif, dan aktif;

d. Meningkatkan belajar bekerja sama;

e. Belajar menghargai pendapat orang lain; 
f. Meningkatkan partisipasi dalam membuat suatu keputusan; dan

g. Peserta didik terlatih untuk mempertanggungjawabkan jawaban yang disampaikannya. Berdasarkan pendapat di atas, dalam penelitian ini penerapan model pembelajaran kooperatif tipe $G I$ mengacu pada langkah-langkah seperti yang diungkapkan oleh Slavin yaitu mengidentifikasikan topik dan mengatur peserta didik ke dalam kelompok, merencanakan tugas yang akan dipelajari, melaksanakan investigasi, menyiapkan laporan akhir, presentasi laporan akhir, dan melakukan evaluasi.

\section{METODE PENELITIAN}

Penelitian ini menggunakan metode tindakan kelas (action research). Dalam bentuk ini, tujuan utama penelitian tindakan kelas ialah untuk meningkatkan praktik-praktik pembelajaran di kelas. Dalam kegiatan ini, guru terlibat langsung secara penuh dalam proses perencanaan, tindakan, observasi dan refleksi. Kehadiran pihak lain dalam penelitian ini peranannya tidak dominan dan sangat kecil.

Penelitian ini mengacu pada perbaikan pembelajaran yang berkesinambungan. Kemmis dan Tagart (1988:14) menyatakan bahwa model penelitian tindakan adalah berbentuk spiral. Tahapan penelitian tindakan pada suatu siklus meliputi perencanaan atau pelaksanaan observasi dan refleksi. Siklus ini berlanjut dan akan dihentikan jika sesuai dengan kebutuhan dan dirasa sudah cukup.

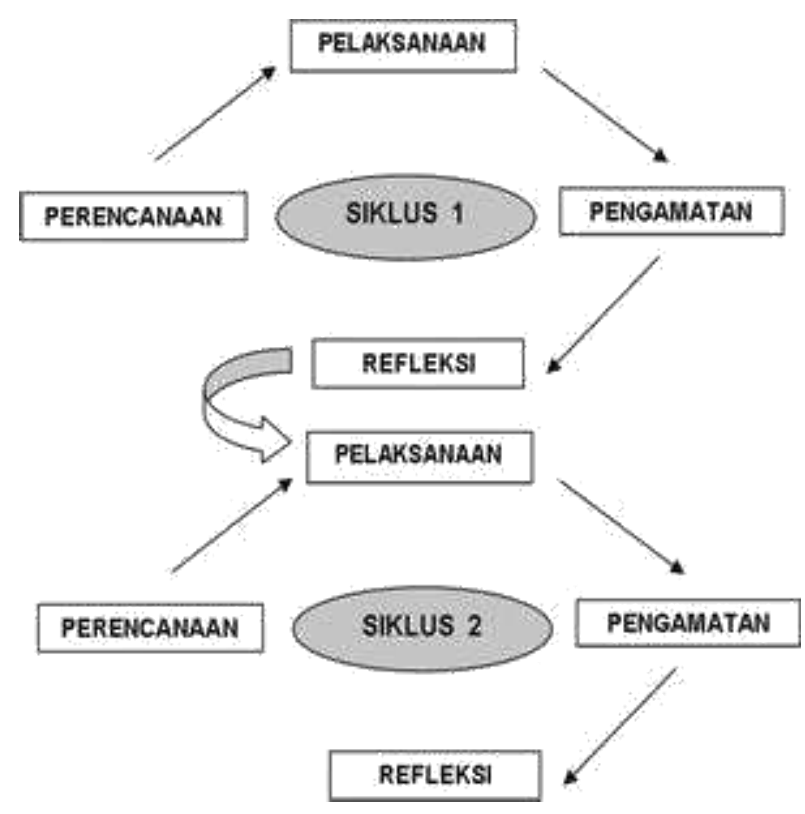

HASIL DAN PEMBAHASAN

Suatu pokok bahasan atau sub pokok bahasan dianggap tuntas secara klasikal jika siswa yang mendapat nilai 65 lebih dari atau sama dengan 85\%, sedangkan seorang siswa dinyatakan tuntas belajar pada pokok bahasan atau sub pokok bahasan tertentu jika mendapat nilai minimal 65 .

Pada akhir proses pembelajaran siklus 1 siswa diberi tes formatif I dengan tujuan untuk mengetahui tingkat keberhasilan siswa dalam proses belajar mengajar yang telah dilakukan. Berdasarkan penelitian pada siklus 1 aspek-aspek yang mendapatkan kriteria kurang baik adalah memotivasi siswa, menyampaikan tujuan pembelajaran, 
pengelolaan waktu, dan antusias. Keempat aspek yang mendapat penilaian kurang baik di atas, merupakan suatu kelemahan yang terjadi pada siklus I dan akan dijadikan bahan kajian untuk refleksi dan revisi yang akan dilakukan pada siklus II.

Aktifitas guru yang paling dominan pada siklus I adalah membimbing dan mengamati siswa dalam menemukan konsep, yaitu $21,7 \%$. Aktifitas lain yang presentasinya cukup besar adalah memberi umpan balik/evaluasi/tanya jawab dan menjelaskan materi yang sulit yaitu masing-masing sebesar 18,3\% dan $13,3 \%$. Sedangkan aktifitas siswa yang paling dominan adalah mengerjakan/memperhatikan penjelasan guru, yaitu 22,5\%. Aktifitas lain yang presentasinya cukup besar adalah bekerja dengan sesama anggota kelompok, diskusi antar siswa/antara siswa dengan guru, dan membaca buku yaitu masing-masing 18,7\%, 14,4 dan $11,5 \%$.

\section{Siklus I}

Pada siklus I secara garis besar kegiatan belajar mengajar dengan pembelajaran Kooperatif tipe GI sudah dilaksanakan dengan baik, walaupun peran guru masih cukup dominan untuk memberikan penjelasan dan arahan karena model tersebut masih dirasakan baru oleh siswa. Berikutnya adalah rekapitulasi hasil tes formatif siswa seperti terlihat pada tabel berikut:

Tabel 1. Rekapitulasi Hasil Tes Formatif Siswa Pada Siklus I

\begin{tabular}{l|l|l}
\hline No & Uraian & $\begin{array}{l}\text { Hasil } \\
\text { Siklus I }\end{array}$ \\
\hline 1. & Nilai rata-rata tes & 67,70 \\
2. & formatif & 29 \\
3. & Jumlah siswa yang & 72,5 \\
& tuntas belajar & \\
& $\begin{array}{l}\text { Presentase } \\
\text { ketuntasan belajar }\end{array}$ \\
\hline
\end{tabular}

Dari tabel di atas dapat dijelaskan bahwa dengan menerapkan pembelajaran kooperatif tipe GI diperoleh nilai rata-rata presentasi belajar siswa adalah 67,70 dan ketuntasan belajar mencapai $72,5 \%$ atau ada 29 siswa dari 40 siswa sudah tuntas belajar. Hasil tersebut menunjukkan bahwa pada siklus I secara klasikal siswa belum tuntas belajar, karena siswa yang belum memperoleh nilai $\geq 65$ hanya sebesar $72,5 \%$ lebih kecil dari presentase ketuntasan yang dikehendaki yaitu sebesar $85 \%$. Hal ini disebabkan karena siswa masih merasa baru dalam mengerti apa yang dimaksudkan dan digunakan guru dengan pembelajaran kooperatif tipe GI.

\section{Siklus II}

Pada akhir proses belajar mengajar siswa diberi tes formatif II dengan tujuan untuk mengetahui tingkat keberhasilan siswa dalam proses belajar mengajar 
yang telah dilakukan instrumen yang digunakan adalah tes formatif II. Pada siklus II, tampak aspek-aspek yang diamati pada kegiatan belajar mengajar yang dilaksanakan oleh guru dengan menerapkan pembelajaran kontekstual model pengajaran Learning Together mendapatkan penilaian yang cukup baik dari pengamat. Maksudnya dari seluruh penilaian tidak terdapat nilai kurang. Namun demikian penelitian tersebut belum merupakan hasil yang optimal, untuk itu ada beberapa aspek yang perlu mendapatkan perhatian untuk menyempurkan penerapan belajar selanjutnya. Aspek-aspek tersebut adalah memotivasi siswa, membimbing siswa merumuskan kesimpulan/menemukan konsep dan pengolahan waktu.

Dengan penyempurnaan aspekaspek di atas dalam penerapan pembelajaran kooperatif tipe $\mathrm{Gl}$ diharapakan siswa dapat menyimpulkan apa yang telah mereka pelajari dan mengemukakan pendapatnya, sehingga mereka akan lebih memahami tentang apa yang telah mereka lakukan.

Aktifitas guru yang paling dominan pada siklus II adalah membimbing dan mengamati siswa dalam menemukan konsep, yaitu $25 \%$. Jika dibandingkan dengan siklus I, aktifitas ini mengalami peningkatan. Aktifitas guru yang mengalami penurunan adalah memberi umpan balik/evaluasi/tanya jawab (16,6\%), menjelaskan materi yang sulit $(11,7)$. Meminta siswa mendiskusikan dan menyajikan hasil kegiatan $(8,2 \%)$, dan membimbing siswa merangkum pelajaran $(6,7 \%)$.

Sedangkan untuk aktifitas siswa yang paling dominan pada siklus II adalah bekerja dengan sesama anggota kelompok yaitu (21\%). Jika dibandingkan dengan siklus I, aktifitas ini mengalami peningkatan. Aktifitas siswa yang mengalami penurunan adalah mendengarkan/memperhatikan penjelasan guru (17,9\%). Diskusi antar siswa/antara siswa dengan guru (13,8\%), menulis yang relevan dengan $\operatorname{KBM}(7,7 \%)$ dan merangkum pembelajaran (6,7\%). Adapun aktifitas siswa yang mengalami peningkatan adalah membaca buku $(12,1 \%)$, menyajikan hasil pembelajaran (4,6\%), menanggapi/mengajukan pertanyaan/ide $(5,4 \%)$ dan mengerjakan tes evaluasi $(10,8 \%)$. Berikutnya adalah rekapitulasi hasil tes formatif siswa terlihat pada tabel berikut:

Tabel 6. Rekapitulasi Hasil Tes Formatif Siswa Pada Siklus II

\begin{tabular}{l|l|l}
\hline No & Uraian & $\begin{array}{l}\text { Hasil } \\
\text { Siklus }\end{array}$ \\
\hline 1. & Nilai rata-rata tes & 73,10 \\
2. & formatif & 32 \\
3. & Jumlah siswa yang & 80 \\
& $\begin{array}{l}\text { tuntas belajar } \\
\text { Presentase ketuntasan } \\
\text { belajar }\end{array}$ \\
\hline
\end{tabular}


Dari tabel di atas diperoleh nilai rata-rata prestasi belajar siswa adalah 73,10 dan ketuntasan belajar mencapai 80,0\% atau ada 32 siswa dari 40 siswa sudah tuntas belajar. Hasil ini menunjukkan bahwa pada siklus II ini ketuntasan belajar secara klasikal telah mengalami peningkatan sedikit lebih baik dari siklus I. adanya peningkatan hasil belajar siswa ini karena setelah guru menginformasikan bahwa setiap akhir pelajaran akan selalu diadakan tes, sehingga pada pertemuan berikutnya siswa lebih termotivasi untuk belajar. Selain itu siswa jua sudah mulai mengerti apa yang dimaksudkan dan diinginkan guru dengan menerapkan pembelajaran kooperatif tipe GI.

\section{Siklus III}

Pada akhir proses pembelajaran siswa diberi tes formatif III dengan tujuan untuk mengetahui tingkat keberhasilan siswa dalam proses belajar mengajar yang telah dilakukan. Instrumen yang dilakukan adalah tes formatif III. Dari hasil siklus III, dapat dilihat aspek-aspek yang diamati pada kegiatan belajar mengajar (siklus III) yang dilaksanakan oleh guru dengan menerapkan pembelajaran kontekstual model pengajaran Learning Together mendapatkan penilaian cukup baik dari pengamatan adalah memotivasi siswa, membimbing siswa merumuskan kesimpulan/menemukan konsep, dan pengelolaan waktu.

Penyempurnaan aspek-aspek di atas dalam menerapkan pembelajaran kooperatif tipe $\mathrm{Gl}$ diharapkan dapat berhasil semaksimal mungkin. Aktifitas guru yang paling dominan pada siklus III adalah membimbing dan mengamati siswa dalam menemukan konsep yaitu 22,6\%, sedangkan aktifitas menjelaskan materi yang sulit dan memberi umpan balik/evaluasi/tanya jawab menurun masing-masing sebesar (10\%) dan $(11,7 \%)$. Aktifitas lain yang mengalami peningkatan adalah mengaitkan dengan pelajaran sebelumnya $(10 \%)$, menyampaikan materi/strategi/langkahlangkah $(13,3 \%)$, meminta siswa menyajikan dan mendiskusikan hasil kegiatan (10\%), dan membimbing siswa merangkum kegiatan (10\%). Adapun aktifitas yang tidak mengalami perubahan adalah menyampaiakan tujuan $(6,7 \%)$ dan memotivasi siswa $(6,7 \%)$.

Sedangkan aktifitas siswa yang paling dominan pada siklus III adalah bekerja dengan sesama anggota kelompok, yaitu $(22,1 \%)$ dan mendengarkan/memperhatikan pelajaran guru $(20,8 \%)$, aktifitas yang mengalami peningkatan adalah membaca buku siswa $(13,1 \%)$ dan siklus antar siswa/antara siswa dengan guru $(15,0 \%)$, sedangkan aktifitas yang lainnya mengalami penurunan. 
Berikutnya adalah rekapitulasi hasil tes formatif siswa seperti terlihat pada tabel berikut:

Tabel 9. Hasil Tes Formatif Siswa Pada Siklus III

\begin{tabular}{l|l|l}
\hline No & Uraian & Hasil Siklus \\
\hline 1. & Nilai rata-rata tes & 78,15 \\
2. & formatif & 37 \\
3. & Jumlah siswa yang & 92,5 \\
& tuntas belajar & \\
& $\begin{array}{l}\text { Presentase } \\
\text { ketuntasan belajar }\end{array}$ & \\
\hline
\end{tabular}

Berdasarkan tabel di atas diperoleh nilai rata-rata tes formatif sebesar 78,15 dari 40 siswa yang telah tuntas sebanyak 37 siswa dan 3 siswa belum mencapai ketuntasan belajar. Maka secara klasikal ketuntasan belajar yang telah tercapai sebesar 92,5\% (termasuk kategori tuntas). Hasil pada siklus III ini mengalami peningkatan hasil belajar pada siklus II. Peningkatan hasil belajar pada siklus III ini dipengaruhi oleh adanya peningkatan kemampuan guru dalam menerapkan pembelajaran kooperatif tipe GI, sehingga siswa menjadi lebih terbiasa dengan pembelajaran seperti ini, sehingga siswa lebih mudah dalam memahami materi yang telah diberikan.

Pada siklus III guru guru telah menerapkan pembelajaran kooperatif tipe Gl dengan baik, dan dilihat dari aktifitas siswa serta hasil belajar siswa pelaksanaan proses belajar mengajar sudah belajar dengan baik, maka tidak diperlukan revisi terlalu banyak. Tetapi yang perlu diperhatikan untuk tindak selanjutnya adalah memaksimalkan dan mempertahankan apa yang telah ada dengan tujuan agar pada pelaksanaan proses belajar mengajar selanjutnya penerapan pembelajaran kontekstual model pengajaran Learning Together dapat meningkatkan proses belajar mengajar, sehingga tujuan pembelajaran dapat tercapai.

\section{Ketuntasan Hasil Belajar Siswa}

Melalui hasil penelitian ini menunjukkan bahwa pembelajaran kooperatif tipe GI memiliki dampak positif dalam meningkatkan prestasi belajar siswa. Hal ini dapat dilihat dari semakin mantapnya pemahaman siswa terhadap materi yang disampaikan guru (ketuntasan belajar meningkat dari siklus I, II, dan III) yaitu masing-masing 72,5\%, 80,0\%, dan 92,5\%. Pada siklus III ketuntasan belajar siswa secara klasikal telah tercapai.

\section{Kemampuan Guru dalam Mengelola Pembelajaran}

Berdasarkan analisis data diperoleh aktifitas siswa dalam proses belajar mengajar dengan menerapkan pembelajaran kontekstual model pengajaran berbasis masalah dalam setiap siklus mengalami peningkatan. Hal ini berdampak positif terhadap prestasi belajar siswa yaitu dapat ditunjukkan dengan meningkatnya nilai rata-rata 
siswa pada setiap siklus yang terus mengalami peningkatan.

\section{PENUTUP}

\section{Simpulan}

Berdasarkan hasil penelitian yang telah dipaparkan selama tiga siklus, hasil seluruh pembahasan serta analisis yang telah dilakukan dapat disimpulkan sebagai berikut:

1. Pembelajaran kooperatif tipe GI dapat meningkatkan kualitas pembelajaran sejarah.

2. Pembelajaran kooperatif tipe GI memiliki dampak positif dalam meningkatkan prestasi belajar siswa yang ditandai dengan peningkatan ketuntasan belajar siswa dalam setiap siklus, yaitu siklus I (72,5\%), siklus II (80,0\%), siklus III (92,5\%).

3. Pembelajaran kooperatif tipe $\mathrm{Gl}$ dapat menjadikan siswa merasa dirinya mendapat perhatian dan kesempatan untuk menyampaikan pendapat, gagasan, ide dan pertanyaan.

4. Siswa dapat bekerja secara mandiri maupun kelompok, serta mampu mempertanggungjawabkan segala tugas individu maupun kelompok.

5. Penerapan pembelajaran kooperatif tipe GI mempunyai pengaruh positif, yaitu dapat meningkatkan motivasi belajar siswa.
Saran

Dari hasil penelitian yang diperoleh dari uraian sebelumnya agar proses belajar mengajar sejarah lebih efektif dan lebih memberikan hasil yang optimal bagi siswa, maka disampaikan saran sebagai berikut :

1. Untuk melaksanakan pembelajaran kooperatif tipe Gl memerlukan persiapan yang cukup matang, sehingga guru harus mampu menentukan atau memilih topik yang benar-benar bisa diterapkan dengan pembelajaran kooperatif tipe GI dalam proses belajar mengajar, sehingga diperoleh hasil yang optimal.

2. Dalam rangka meningkatkan prestasi belajar siswa, guru hendaknya lebih sering melatih siswa dengan berbagai metode pengajaran, walau dalam taraf yang sederhana, di mana siswa nantinya dapat menemukan pengetahuan baru, memperoleh konsep dan keterampilan, sehingga siswa berhasil atau mampu memecahkan masalah-masalah yang dihadapinya.

3. Perlu adanya penelitian yang lebih lanjut, karena hasil penelitian ini hanya dilakukan di SMA Negeri 1 Puggur kelas XII IPA tahun pelajaran 2015/2016.

4. Untuk penelitian yang serupa hendaknya dilakukan perbaikan- 
perbaikan, agar diperoleh hasil yang lebih baik.

\section{DAFTAR PUSTAKA}

Abdurrahman. 1999. Pendidikan bagi anak berkesulitan belajar. Jakarta: rineka cipta

Anita, lie. 2008. Cooperative Learning: Mempraktikkan Cooperative Learning di Ruang-Ruang Kelas. Jakarta: Grasindo

Dimyati dan Mudjiono. 1999. Belajar dan pembelajaran. Jakarta: rineka cipta

Kemmis dan Tagart. 1988. The Action Research Planner. Victoria: Deakin

Paul Suparno. 2001. Filsafat kontruktivisme dalam pendidikan. Yogyakarta: Kanisius.

Slavin, Robert E. 2009. cooverative lerning (teori, riset, praktik). Bandung: Nusa Media.

Soekamto, Toeti. 1997. Teori Belajar dan Model Pembelajaran. Jakarta: PAU-PPAI. Universitas Terbuka. 